\title{
What is known about Tritrichomonas foetus infection in cats?
}

\author{
O que sabemos sobre a infecção por Tritrichomonas foetus em gatos? \\ Bethânia Ferreira Bastos $^{1}$ (D); Flavya Mendes de Almeida ${ }^{1}$ (D); Beatriz Brener ${ }^{2}$ \\ ${ }^{1}$ Departamento de Clínica e Patologia Veterinária, Faculdade de Medicina Veterinária, Universidade Federal Fluminense - UFF, \\ Niterói, RJ, Brasil \\ ${ }^{2}$ Departamento de Microbiologia e Parasitologia, Universidade Federal Fluminense - UFF, Niterói, RJ, Brasil
}

Received September 6, 2018

Accepted January 29, 2019

\begin{abstract}
Tritrichomonas foetus is a parasite that has been definitively identified as an agent of trichomonosis, a disease characterized by chronic diarrhea. T. foetus colonizes portions of the feline large intestine, and manifests as chronic and recurrent diarrhea with mucus and fresh blood, which is often unresponsive to common drugs. Diagnosis of a trichomonad infection is made by either the demonstration of the trophozoite on a direct fecal smear, fecal culture and subsequent microscopic examination of the parasite, or extraction of DNA in feces and amplification by the use of molecular tools. T. foetus is commonly misidentified as other flagellate protozoa such as Giardia duodenalis and Pentatrichomonas hominis. Without proper treatment, the diarrhea may resolve spontaneously in months to years, but cats can remain carriers of the parasite. This paper intends to serve as a source of information for investigators and veterinarians, reviewing the most important aspects of feline trichomonosis, such as trichomonad history, biology, clinical manifestations, pathogenesis, world distribution, risk factors, diagnosis, and treatment.
\end{abstract}

Keywords: Trichomonosis, domestic cat, diarrhea, endoparasites.

\section{Resumo}

Tritrichomonas foetus é um parasito que foi identificado definitivamente como agente de tricomoníase, caracterizada por diarreia crônica. T. foetus coloniza porçôes do intestino grosso dos felinos e se manifesta como uma diarreia crônica e recorrente, com muco e sangue, geralmente irresponsiva às drogas comumente usadas no tratamento. O diagnóstico da infecção por tricomonadídeos é feito pela demonstração de trofozoítos no exame direto de fezes frescas, cultura fecal e subsequente exame microscópico ou extração do DNA do parasito na amostra fecal e amplificação, utilizando-se técnicas moleculares. T. foetus é comumente confundido com outros protozoários flagelados, como Giardia duodenalis e Pentatrichomonas hominis. Sem tratamento adequado, a diarreia pode cessar espontaneamente em meses ou anos, porém os gatos podem permanecer portadores do parasito. Esse artigo pretende servir como fonte de informação para pesquisadores e veterinários, revisando os mais importantes aspectos da tricomoníase felina, como histórico, biologia, manifestaçôes clínicas, patogênese, distribuição mundial, fatores de risco, diagnóstico e tratamento.

Palavras-chave: Trichomoníase, gato doméstico, diarreia, endoparasitos.

\section{Introduction}

Tritrichomonas foetus is a trichomonad that was first described as a bovine venereal pathogen, causing infertility, abortion, and endometritis (FELLEISEN, 1999; STOCKDALE et al., 2006). More than a decade ago, $T$. foetus was also identified in the feces of domestic cats with chronic diarrhea (GOOKIN et al., 1999; LEVY et al., 2003). Trichomonads had been observed in cats with and without diarrhea (DA CUNHA \& MUNIZ, 1922;

*Corresponding author: Beatriz Brener. Departamento de Microbiologia e Parasitologia, Universidade Federal Fluminense, Rua Professor Hernani Melo, 101, São Domingos, CEP 24210-130, Niterói, RJ, Brasil.

e-mail: brener@vm.uff.br
JORDAN, 1956), but was considered to be commensal and opportunistic (DIMSKI, 1989; BARR, 1998). For a long time, T. foetus may have been confused with Pentatrichomonas sp. or Giardia sp. under microscopic analysis (GOOKIN et al., 1999); however, with genetic identification through molecular tools, $T$. foetus was considered the causal agent of feline trichomonosis in 2003 (LEVY et al., 2003).

Since feline trichomonosis has been identified as an emerging gastrointestinal disease, researchers have turned their interest to understanding its etiology, epidemiology, and pathogenesis, as well as diagnosis and treatment (GOOKIN et al., 1999, 2006, 2010; GRAY et al., 2010). 


\section{Taxonomy}

Trichomonads of the species Tritrichomonas foetus are anaerobic protozoan parasites placed in the phylum Parabasalia, order Trichomonadida, and family Trichomonadidae (BRUGEROLLE \& LEE, 2000). A new rank system classifies trichomonads as [Excavata: Parabasalia: Trichomonadida] (ADL et al., 2005).

\section{History}

Trichomonosis was first described in a cat in Brazil by Da Cunha \& Muniz (1922), who named the agent Trichomonas felis. Years later, Brumpt (1925) found trichomonads with three to five anterior flagella in dogs and cats in France, adopting the name Trichomonas felis for the parasite present in both animals. One year later, Tanabe identified Pentatrichomonas sp. in a cat, naming the parasite Pentatrichomonas felis (TANABE, 1926).

Kessel (1928) observed natural and experimental trichomonosis in nine kittens. These animals presented with diarrhea that progressed to dysentery, and they died within 10 days of infection.

In 1956, a young cat presenting with chronic diarrhea was diagnosed with trichomonosis, described as an infection caused by Trichomonas sp. (JORDAN, 1956).

From 1956 to 1996, there was a lack of reports about feline trichomonosis, presumably because of the assumption that the trichomonads were non-pathogenic commensal species and only existed when there was a pre-existing enteric disease (DIMSKI, 1989; BARR, 1998; GOOKIN et al., 1999). In 1996, based on the microscopic examination of fecal smears, Romatowski (1996, 2000) identified the trichomonads as Pentatrichomonas hominis, and causing a mucoid diarrhea in kittens and adult cats.

In 2001, after a molecular assay to analyze the gene $18 \mathrm{~S}$ rRNA present in trichomonad isolates, the identity of the agent as Tritrichomonas foetus was revealed, with $99.9 \%$ similarity (LEVY et al., 2003).

Tritrichomonas foetus has also been identified in the reproductive tract of a cat with pyometra in Norway, although the cause of the uterine infection was attributed to the bacteria Streptococcus sp., which was present in the genital secretion (DAHLGREN et al., 2007).

Gray et al. (2010) examined the reproductive tracts of 15 cats previously diagnosed with intestinal infection caused by $T$. foetus. They used light microscopy, immunohistochemical analysis, and PCR assay, and found no evidence of the parasite in the reproductive tracts.

\section{Molecular Approach}

Several studies have investigated the agent present in cattle and the possibility that this was the source of the feline infection. An epidemiological study of cats found no association between T. foetus infection and proximity to cattle (GOOKIN et al., 2004). Studies involving cross-transmission conducted by Stockdale et al. (2007, 2008) indicated phenotypic differences related to infectivity and pathogenicity among the feline and bovine isolates. The molecular characterization of feline isolates compared to cattle showed genetic differences. Thus, Slapeta et al. (2010) suggested a species-specific distinction of T. foetus between the cattle and cat genotypes. Other researchers have also observed few but consistent genetic differences between cattle and feline isolates. Sun et al. (2012) reported differences in the nucleotides and amino acids of cysteine protease 8 from bovine and feline isolates, elucidating a possible adaptation to their preferred host.

A new name, Tritrichomonas blagburni, was proposed for the feline parasite in order to differentiate it from the bovine parasite (WALDEN et al., 2013). According to the authors, the host specificity, as well as morphological and genetic information, must be considered in any taxonomic evaluation. This is still scientifically controversial, since data obtained from comparative analyzes of the two transcriptomes have failed to confirm that they are two distinct species (MORIN-ADELINE et al., 2014).

In addition, studies suggested that $T$. suis, a trichomonad of the domestic pig, is morphologically indistinguishable from T. foetus. Sequencing of a variable DNA fragment and comparison of gene sequences did not reveal differences between $T$. suis and $T$. foetus bovine isolates. Thus, researchers concluded that $T$. foetus and $T$. suis belong to the same species, proposing that they are synonyms (TACHEZY et al., 2002; LUN et al., 2005).

\section{Morphology}

The parasites $T$. foetus only have a trophozoite stage. They are small flagellates, ranging in size from 10-25 $\mu \mathrm{m}$ in length and $3-15 \mu \mathrm{m}$ in width (GOOKIN et al., 2006). They have a pear-shaped body, one nucleus, three anterior flagella, and a posterior flagellum (WARTONA \& HONIGBERG, 1979). The posterior flagellum travels along the body of the parasite, forming the undulating membrane (GOOKIN et al., 2006). The axostyle, a rigid organelle, extends through the body length of the parasite (LEVINE, 1985), and protrudes from the posterior extremity (GOOKIN et al., 2006).

\section{Life Cycle}

The life cycle is a simple asexual cycle, where the trophozoite multiplies by longitudinal binary division, and transmission occurs directly between hosts via ingestion of trophozoites (GOOKIN et al., 2017).

There is no true cyst stage, but some authors describe that in conditions of environmental stress, such as nutrient scarcity, drug action, or abrupt temperature changes, there may be pseudo-cyst formation. In this case, the flagella are internalized, but the cell is not surrounded by a cyst wall (PEREIRA-NEVES et al., 2003; PEREIRA-NEVES \& BENCHIMOL, 2009; ROSA et al., 2015).

\section{Transmission}

The transmission of $T$. foetus among cats occurs via the fecal-oral route (GOOKIN et al., 1999, 2001). Direct contact with contaminated fresh feces may be sufficient for the transmission of the parasite, since $T$. foetus does not release cysts into the 
environment. However, Hale et al. (2009) showed that T. foetus trophozoites are more resistant to environmental conditions than previously thought, surviving in moist feces for seven days at room temperature $\left(23-24^{\circ} \mathrm{C}\right)$. The ability of the parasite to survive outside the host may be an important factor in the epidemiology of the disease, especially in places with an overpopulation of cats. This survivability also suggests that self and mutual grooming by cats and fecal contamination of the environment are important factors in the epidemiology of the disease (HALE et al., 2009; VAN DER SAAG et al., 2010).

Although the experimental transmission of $T$. foetus between cattle and felines is possible, direct transmission from bovines to cats is not the primary source of infection (STOCKDALE et al., 2008). Gookin et al. (2004) found no association between feline infection and proximity to cattle.

\section{Risk Factors}

Tritrichomonas foetus is predominantly identified in young cats. Most studies have shown an average age of 12 months or less, ranging in age from 4 weeks to 16 years (GOOKIN et al., 1999, 2004; BURGENER et al., 2009; FREY et al., 2009).

In many studies, infected cats were 1 year old or younger (FOSTER et al., 2004; GOOKIN et al., 2004; YAEGER \& GOOKIN, 2005; STOCKDALE et al., 2009; ARRANZ-SOLÍS et al., 2016). Holliday et al. (2009) found infected cats in a colony with a predominant age of over 1 year. The probable explanation for this discrepancy is that the infection may have entered the population for the first time, and the lack of protection by the immune system allowed older cats as well as young cats to develop clinical signs (HOLLIDAY et al., 2009). Cats, especially those more than 3 years old, may be asymptomatically infected, and can become an important source of parasitic infection for other felines (XENOULIS et al., 2010).

A predisposition to gender among cats infected with $T$. foetus has not been observed in any study (GOOKIN et al., 2004; GUNN-MOORE et al., 2007; BURGENER et al., 2009; STOCKDALE et al., 2009). In most studies, purebred cats are more affected (GUNN-MOORE et al., 2007; BURGENER et al., 2009; FREY et al., 2009; STOCKDALE et al., 2009; BELL et al., 2010; KLEIN et al., 2010). Conversely, two studies have shown that the infection is also common in mixed-breed cats (GOOKIN et al., 1999; HOLLIDAY et al., 2009). Since feline infection by T. foetus is more frequent in catteries and shelters (GOOKIN et al., 1999; FOSTER et al., 2004), it is not known whether infection is more frequent in purebred cats because of a genetic predisposition or because these cats usually live in places with an agglomeration of T. foetus (HOLLIDAY et al., 2009).

The role of overpopulation and management in contrast to genetic predisposition may be the answer to the higher prevalence of infection in purebred cats. This explanation is supported by the high prevalence of infection in a group of mixed-breed cat residents in a shelter with poor sanitary conditions (HOLLIDAY et al., 2009).

Although Gookin et al. (2004) did not find a significant association between $T$. foetus infection and litter boxes, the importance of feline population density is associated with the facility of transmission through boxes (GOOKIN et al., 2007).

It is not known whether the animal's immune status influences the pathogenesis of $T$. foetus infection. On the other hand, the high prevalence of infection in young cats may indicate a susceptibility to infection in the case of an immature immune system (GOOKIN et al., 1999). However, an experimental study did not observe a worsening of the diarrhea when an immunosuppressive dose of prednisolone was administered (GOOKIN et al., 2001). In addition, there seems to be no association between $T$. foetus infection and immunosuppressive diseases, such as those caused by feline leukemia virus (FeLV) and feline immunodeficiency virus (FIV) (GOOKIN et al., 1999; ROSADO et al., 2007).

Coinfections with other enteropathogens are often observed in cats with $T$. foetus (GOOKIN et al., 2004). Some authors question whether $T$. foetus is an isolated cause of diarrhea or if concomitant infections lead cats to be more vulnerable to the parasite (STOCKDALE et al., 2009).

Several studies suggest that coinfection with Giardia sp. is common. Risk and associated factors common to trichomonosis and giardiasis include diarrhea, high population density, and young age (GOOKIN et al., 2004). Gookin et al. (2004) found a coinfection of $T$. foetus and Giardia sp. in $12 \%$ of the cats, but this association was not significant. Steiner et al. (2007) observed that most cats infected in their study were also positive for Giardia sp., and Bissett et al. (2008) reported that 66\% of cats studied were coinfected.

Coinfection with coccidia is also frequently reported (STOCKDALE et al., 2009; GOOKIN et al., 2001, 2005; BISSETT et al., 2008). Gookin et al. (2001) experimentally inoculated eight cats with a feline $T$. foetus isolate, four of which were already infected with Cryptosporidium spp. After inoculation with the $T$. foetus isolate, cats infected with Cryptosporidium spp. developed earlier and more severe diarrhea and had a greater number of trophozoites in the direct exam than did cats without coccidia. On the other hand, there was no difference in the number of oocysts removed.

\section{Prevalence}

Studies with feline trichomonosis in several countries have indicated that $T$. foetus is prevalent among domestic cats around the world (STEINER et al., 2007). In Brazil, there are only three reports of $T$. foetus infection in domestic cats. In Rio de Janeiro, Santos et al. (2015) found a prevalence of 5.2\% of different-aged cats with diarrhea, using culture and PCR. In Sáo Paulo, Hora et al. (2017) described a clinical case of T. foetus infection in a chronic diarrheic 7-month-old cat and Duarte et al. (2018) observed five infected cats $(3.6 \%)$.

In summary, the global prevalence of $T$. foetus infection in domestic cats, with and without diarrhea, ranges from $0-81.8 \%$, according to the number of samples analyzed, the diagnostic method used, geographical region, and lifestyle of the cat population (Table 1). 
Table 1. Prevalence of Tritrichomonas foetus infection in domestic cats, according to the country, fecal sample source, and diagnostic method used.

\begin{tabular}{|c|c|c|c|c|c|}
\hline Country & Fecal Sample/ Source & Diagnostic method & Case report & Prevalence (\%) & Reference \\
\hline Australia & Cats from clinic & $\begin{array}{l}\text { Direct exam; } \\
\text { fecal culture; } \\
\text { PCR; } \\
\text { sequencing }\end{array}$ & 16 & - & BISSETT et al., 2008 \\
\hline Australia & $\begin{array}{l}\text { Cats from cattery }(82) \\
\text { and shelters }(52)\end{array}$ & $\begin{array}{l}\text { Fecal culture; } \\
\text { PCR }\end{array}$ & - & 0 & BISSETT et al., 2009 \\
\hline Australia & Cats from clinic & $\begin{array}{l}\text { Direct exam; } \\
\text { PCR }\end{array}$ & 13 & - & BELL et al., 2010 \\
\hline Austria and Germany & Fecal samples (31) & $\begin{array}{c}\text { PCR; } \\
\text { sequencing }\end{array}$ & - & 19.4 & STEINER et al., 2007 \\
\hline Austria & Necropsy (96) & $\begin{array}{c}\text { CISH; } \\
\text { PCR; } \\
\text { sequencing }\end{array}$ & - & 2.9 & MOSTEGL et al., 2012 \\
\hline Brazil & Cats without diarrhea & Fecal culture; PCR & - & 5.2 & SANTOS et al., 2015 \\
\hline Brazil & Cat with diarrhea & $\begin{array}{l}\text { Direct exam; } \\
\text { PCR }\end{array}$ & 1 & - & HORA et al., 2017 \\
\hline Brazil & $\begin{array}{c}\text { Cats with and without } \\
\text { diarrhea }\end{array}$ & $\begin{array}{l}\text { Direct exam; } \\
\text { PCR }\end{array}$ & - & 3.9 & DUARTE et al., 2018 \\
\hline Canada & Cats from clinic & PCR & 1 & - & PHAM, 2009 \\
\hline Canada & Cats from cat show & Fecal culture; PCR & - & 23.6 & HOSEIN et al., 2013 \\
\hline Canada & Cats from clinic & $\begin{array}{c}\text { Fecal culture; } \\
\text { PCR }\end{array}$ & - & 0.7 & HOSEIN et al., 2013 \\
\hline Canada & Cats from shelter & Fecal culture & - & 0 & RAAB et al., 2016 \\
\hline China & Cats with diarrhea & $\begin{array}{l}\text { Direct exam; } \\
\text { PCR }\end{array}$ & 29 & - & KÖSTER et al., 2015 \\
\hline Czech Republic & $\begin{array}{c}\text { Cats with and without } \\
\text { diarrhea }\end{array}$ & Fecal culture & - & 0 & CEPLECHA et al., 2017 \\
\hline France & Cats from cat show & Fecal culture & - & 14.3 & PROFIZI et al., 2013 \\
\hline Germany & Cats with diarrhea & $\begin{array}{l}\text { Direct exam; } \\
\text { PCR; } \\
\text { sequencing }\end{array}$ & 3 & - & SCHREY et al., 2009 \\
\hline Germany & Cats with diarrhea & $\begin{array}{l}\text { Direct exam; } \\
\text { fecal culture }\end{array}$ & - & 3.4 & KLEIN et al., 2010 \\
\hline Germany & Cats from cat show & $\begin{array}{l}\text { Fecal culture; } \\
\text { PCR; } \\
\text { sequencing }\end{array}$ & - & 15.7 & KUEHNER et al., 2011 \\
\hline Greece & $\begin{array}{c}\text { Cats with and without } \\
\text { diarrhea }\end{array}$ & PCR & - & 31 & BELL et al., 2010 \\
\hline Greece & $\begin{array}{c}\text { Cats with and without } \\
\text { diarrhea }\end{array}$ & PCR & - & 20 & XENOULIS et al., 2010 \\
\hline Italy & Cats from catteries & $\begin{array}{l}\text { Direct exam; } \\
\text { fecal culture; } \\
\text { PCR }\end{array}$ & - & 32.4 & HOLLIDAY et al., 2009 \\
\hline Italy & $\begin{array}{c}\text { Cats with and without } \\
\text { diarrhea }\end{array}$ & Fecal culture & - & 0 & MUGNAINI et al., 2012 \\
\hline Italy & Cats without diarrhea & PCR & - & 2.1 & MANCIANTI et al., 2015 \\
\hline Italy & Cats with diarrhea & PCR & - & 5.2 & VERONESI et al., 2016 \\
\hline Japan & Cats with diarrhea & $\begin{array}{l}\text { Fecal culture; } \\
\text { PCR; } \\
\text { sequencing }\end{array}$ & - & 8.8 & DOI et al., 2012 \\
\hline Korea & Cats from clinics & $\begin{array}{l}\text { Direct exam; } \\
\text { fecal culture; } \\
\text { PCR }\end{array}$ & - & 2 & LIM et al., 2010 \\
\hline Netherlands & Cats with diarrhea & PCR & - & 2 & VAN DOORN et al., 2009 \\
\hline New Zealand & Cats from cat show & $\begin{array}{c}\text { Fecal culture; } \\
\text { PCR }\end{array}$ & - & 81.8 & KINGSBURY et al., 2010 \\
\hline
\end{tabular}


Table 1. Continued...

\begin{tabular}{|c|c|c|c|c|c|}
\hline Country & Fecal Sample/ Source & Diagnostic method & Case report & Prevalence (\%) & Reference \\
\hline Norway & Cats from clinics & $\begin{array}{c}\text { Direct exam; } \\
\text { PCR; } \\
\text { sequencing }\end{array}$ & 3 & - & DAHLGREN et al., 2007 \\
\hline Norway & Cats from cat show & $\begin{array}{l}\text { Fecal culture; } \\
\text { PCR; } \\
\text { sequencing }\end{array}$ & - & 21.2 & TYSNES et al., 2011 \\
\hline Poland & Cat with diarrhea & PCR & 1 & - & DĄBROWSKA et al., 2015 \\
\hline Spain & Cats without diarrhea & $\begin{array}{l}\text { Direct exam; } \\
\text { PCR }\end{array}$ & - & 25 & MIRÓ et al., 2011 \\
\hline Spain & Cats with diarrhea & $\begin{array}{l}\text { Fecal culture; } \\
\text { PCR }\end{array}$ & - & 38.7 & $\begin{array}{l}\text { ARRANZ-SOLÍS et al., } \\
2016\end{array}$ \\
\hline Switzerland & $\begin{array}{c}\text { Cats with and without } \\
\text { diarrhea }\end{array}$ & $\begin{array}{l}\text { Fecal culture; } \\
\text { PCR }\end{array}$ & - & 25.7 & BURGENER et al., 2009 \\
\hline Switzerland & Cats with diarrhea & $\begin{array}{l}\text { Fecal culture; } \\
\text { PCR }\end{array}$ & - & 24.4 & FREY et al., 2009 \\
\hline United Kingdom & Cats with diarrhea & PCR & - & 18.8 & PARIS et al., 2014 \\
\hline United Kingdom & Cat with diarrhea & $\begin{array}{l}\text { Direct exam; } \\
\text { PCR }\end{array}$ & 1 & - & $\begin{array}{c}\text { MARDELL \& SPARKES, } \\
2006\end{array}$ \\
\hline United Kingdom & Cats with diarrhea & PCR & - & 14.4 & $\begin{array}{c}\text { GUNN-MOORE et al., } \\
2007\end{array}$ \\
\hline United Kingdom & Cats from clinic & PCR & - & 20 & $\begin{array}{c}\text { GUNN-MOORE \& TEN- } \\
\text { NANT, } 2007\end{array}$ \\
\hline USA & Cats with diarrhea & $\begin{array}{l}\text { Direct exam; } \\
\text { fecal culture }\end{array}$ & 32 & - & GOOKIN et al., 1999 \\
\hline USA & Cats with diarrhea & $\begin{array}{l}\text { Direct exam; } \\
\text { fecal culture; } \\
\text { PCR }\end{array}$ & 26 & - & FOSTER et al., 2004 \\
\hline USA & Cats from cat show & $\begin{array}{l}\text { Direct exam; } \\
\text { fecal culture; } \\
\text { PCR }\end{array}$ & - & 30.8 & GOOKIN et al., 2004 \\
\hline USA & Cats with diarrhea & $\begin{array}{c}\text { Direct exam; } \\
\text { fecal culture; PCR }\end{array}$ & 7 & - & $\begin{array}{c}\text { YAEGER \& GOOKIN, } \\
2005\end{array}$ \\
\hline USA & Cat with diarrhea & $\begin{array}{l}\text { Direct exam; } \\
\text { fecal culture; } \\
\text { PCR }\end{array}$ & 1 & - & GOOKIN et al., 2006 \\
\hline USA & Cats with diarrhea & Fecal culture; PCR & 4 & - & KATHER et al., 2007 \\
\hline USA & Cats with diarrhea & Fecal culture; PCR & 4 & - & ROSADO et al., 2007 \\
\hline USA & Fecal samples & Fecal culture; PCR & - & 9.8 & STOCKDALE et al., 2009 \\
\hline USA & Cats from catteries & $\begin{array}{l}\text { Direct exam; } \\
\text { PCR }\end{array}$ & - & 24.6 & GRAY et al., 2010 \\
\hline USA & Cats with diarrhea & Fecal culture; PCR & - & 5.9 & QUEEN et al., 2012 \\
\hline USA & Cats from clinic & $\begin{array}{l}\text { Direct exam; fecal } \\
\text { culture; PCR }\end{array}$ & 104 & - & XENOULIS et al., 2013 \\
\hline USA & Cats with diarrhea & PCR & - & 39.7 & POLAK et al., 2014 \\
\hline West Indies & $\begin{array}{c}\text { Feral cats and owned } \\
\text { outpatient cats }\end{array}$ & Fecal culture; PCR & - & 0 & YAO et al., 2018 \\
\hline
\end{tabular}

PCR: Polymerase chain reaction, - Not studied.

\section{Pathogenesis}

Because it is a recently described parasite, the pathogenesis of T. foetus infection in cats is still not fully understood (TOLBERT \& GOOKIN, 2016). There are hypotheses on whether the parasite alone could cause clinical signs, or whether feline trichomonosis could be a multifactorial disease, associated with enteric coinfections and host-related factors (GOOKIN et al., 2004).
T. foetus colonizes the ileum, cecum and colon of cats (GOOKIN et al., 2001; STOCKDALE et al., 2008). Experimental works demonstrated the cytotoxic and proteolytic activity of $T$. foetus to mammalian cells (BURGESS \& MCDONALD, 1992). Infection is characterized by moderate lymphoplasmacytic and neutrophilic infiltration of the propria lamina (YAEGER \& GOOKIN, 2005). A reduced colonic epithelium, cryptic hypertrophy, hyperplasia and increased mitotic activity, loss of goblet cells, and microabscesses in 
crypts have been described (SCHREY et al., 2009). Eosinophilic inflammation can also occasionally be observed (YAEGER \& GOOKIN, 2005; SCHREY et al., 2009).

Some factors suggest that bacteria present in the colon are an important part of the pathogenesis of diarrhea in cats infected with T. foetus. For example, diarrhea in these animals is usually slowed down with the administration of antibiotics (GOOKIN et al., 1999, 2001). If these antibiotics directly reduce the bacterial contribution in the pathogenesis of diarrhea or simply reduce the numbers of $T$. foetus by nutrient support depletion is unknown (TOLBERT \& GOOKIN, 2016).

Chronically infected cats may show extensive periods of clinical remission, but relapsing episodes of diarrhea may be triggered by dietary changes or stressful events that could change the colonic microbiota (FOSTER et al., 2004).

\section{Clinical Signals}

The clinical signals vary from subclinical to severe cases of intestinal disease (FOSTER et al., 2004). Experimentally, the signs appeared 2-7 days after oral ingestion (GOOKIN et al., 2001). Clinical signs include chronic or intermittent diarrhea, yellowish-green and malodorous stools, characteristics of colitis, which may include the presence of live blood, mucus, fecal incontinence, tenesmus, and/or flatulence (GOOKIN et al., 2001; XENOULIS et al., 2013). Fecal consistency usually ranges from semi-formed to liquid (SCHREY et al., 2009; XENOULIS et al., 2010). More severe cases may include marked inflammation in the anal region and rectal prolapse (FOSTER et al., 2004; BURGENER et al., 2009).

As expected in a disease that usually affects the large intestine, most infected cats have good body conditions, with no systemic signs (GOOKIN et al., 1999, 2001; TOLBERT \& GOOKIN 2009), although one-fifth of infected cats can show systemic signs, such as anorexia, depression, weight loss, vomiting, and fever (STOCKDALE et al., 2007).

Clinical signs last from 5-24 months, averaging 9 months after diagnosis (FOSTER et al., 2004). The severity of clinical signs varies, ranging from asymptomatic cases to intractable diarrhea (FOSTER et al., 2004; GRAY et al., 2010; XENOULIS et al., 2010).

\section{Diagnostic Tools}

Once the parasite only has the trophozoite phase, it cannot be identified in routine coproparasitological techniques and does not survive refrigeration. Therefore, the diagnosis of T. foetus infection requires more specific procedures (GOOKIN et al., 1999).

Diagnosis can be made by direct examination of fresh feces smear (GOOKIN et al., 1999), fecal culture using specific media (GOOKIN et al., 2003), or PCR amplification (GOOKIN et al., 2002), which is the most widely used method in the literature. In addition, the parasite can be identified via histopathologic analysis of intestinal biopsies (GOOKIN et al., 2001; YAEGER \& GOOKIN, 2005).
Suitable fecal samples include either a freshly voided stool or collected by manual extraction with the aid of a fecal loop or by a colon flush technique, in which approximately $10 \mathrm{ml}$ of sterile saline is injected through a catheter into the colon and then aspirated (TOLBERT \& GOOKIN, 2009; YAO \& KOSTER, 2015).

Fecal samples should be fresh, free of contaminating litter, and kept unrefrigerated before testing (TOLBERT \& GOOKIN, 2009). To maximize the sensitivity of the direct examination and culture, feces should be analyzed within a 6-hour period after collection (HALE et al., 2009).

Diagnostic methods require the presence of parasite trophozoites in the feces. Fluctuations in the release of trophozoites are characteristic of venereal trichomonosis in cattle (SKIRROW et al., 1985). Similarly, in cats, the elimination of trophozoites in feces is probably intermittent (GOOKIN et al., 2001; STOCKDALE et al., 2008; HALE et al., 2009), and can be reduced by recent antibiotic therapy (GOOKIN et al., 1999; FOSTER et al., 2004; TOLBERT \& GOOKIN, 2009).

\section{Direct fecal exam}

The identification of motile trophozoites present in a fecal sample diluted with saline by direct examination using $200 \times$ or $400 \times$ optical microscopy is a simple and inexpensive means to detect $T$. foetus in feline feces. However, this test has low specificity and sensitivity (HALE et al., 2009).

The sensitivity of the technique is low because it depends on the presence of a large number of viable trophozoites in the fecal sample (HALE et al., 2009), and was below $2 \%$ in experimentally infected cats (GOOKIN et al., 2001, 2003) and 4\% in naturally infected cats (GOOKIN et al., 2003, 2004). Detection can be optimized by using fresh, non-refrigerated, and diarrheal stools and performing multiple test analyses (GOOKIN et al., 2001, 2004).

The specificity of the exam depends on the professional, who must be trained to differentiate $T$. foetus from other protozoan trophozoites, such as Giardia sp. (GOOKIN et al., 2003). The trophozoites of T. foetus are pear shaped and have three anterior flagella, one nucleus, and an undulating membrane. The trophozoites of Giardia sp. have no undulating membrane, two nuclei, and one ventral disc. Trophozoites of T. foetus and Giardia sp. have the same size but move differently. The trophozoites of Giardia sp. have a falling leaf-like motility, while those of T. foetus move progressively (GOOKIN et al., 2004).

T. foetus and $P$. hominis cannot be easily distinguished morphologically from each another by examining living specimens. P. hominis has five anterior flagella, but these flagella are difficult to enumerate in a moving trophozoite (LEVY et al., 2003). Gookin et al. (2007) argue that $P$. hominis infection does not appear to contribute to the failure to diagnose trichomonosis, since $P$. hominis infection would always be accompanied by $T$. foetus, but the reverse is not true. Ceplecha et al. (2013) disagreed, and affirmed that the survival of $P$. hominis in fecal stools is a factor to be considered. According to them, confirmation of the true agent by molecular techniques is important to avoid the unnecessary use of ronidazole, the treatment of choice for feline trichomonosis, which has neurotoxic potential. 


\section{Fecal culture}

Fecal culture is a sensitive and specific method for the diagnosis of T. foetus infection in cats (GOOKIN et al., 2003). Two culture media are most commonly used and validated for parasite growth. The 'In Pouch ${ }^{\mathrm{TM}} \mathrm{TF}-$ Feline' culture pouch system (Biomed Diagnostics, White City, Oregon, USA) is an easy-to-use commercial test that can be performed within veterinary clinics because of its practicality. This pouch can be incubated at $37^{\circ} \mathrm{C}$ or room temperature $\left(23-24^{\circ} \mathrm{C}\right)$, but the trichomonads multiply quickly at $37^{\circ} \mathrm{C}$ (GOOKIN et al., 2004). In Pouch culture systems inoculated with more than $0.1 \mathrm{~g}$ of cat feces, led to overgrowth of gas-producing bacteria or yeast within 24 hours, which inhibited its usefulness for diagnosis (GOOKIN et al., 2003). The other medium is modified Diamond's medium that is enriched with nutrients and antibiotics, which requires sterilization and incubation at $37^{\circ} \mathrm{C}$ (GOOKIN et al., 2004). The culture is examined under optical microscopy from days 2-12 after incubation, to identify mobile trophozoites. It may take up to 7 days for the organism to become detectable (GOOKIN et al., 2003).

Gookin et al. (2004) found no significant difference between the two culture media, while Hale et al. (2009) determined a sensitivity of $83 \%$ and $100 \%$ for the InPouch ${ }^{\mathrm{TM}}$ commercial test and the modified Diamond's medium methods, respectively. The limitation of this diagnostic method is that it requires viable trophozoites. At low temperatures and desiccation, T. foetus may die. Researchers have shown that feces maintained at room temperature for up to $6 \mathrm{~h}$ represent a suitable material for diagnostic investigation through fecal culture (HALE et al., 2009). The addition of saline solution to the fecal is recommended if the sample is transported or stocked prior to culturing. In addition, the fecal sample should be free of sand, which could desiccate the sample and kill the parasite (GOOKIN et al., 2003).

\section{Polymerase Chain Reaction (PCR)}

The PCR method is considered a specific and more sensitive detection method for $T$. foetus, since it does not require viable trophozoites (GOOKIN et al., 2002; VERMEULEN, 2009). The solution of the fecal sample or culture can be sedimented in a centrifuge and submitted for PCR analysis (TOLBERT \& GOOKIN., 2009). A study by Gookin et al. (2004) found a sensitivity of $94.4 \%$ (34/36). On the other hand, the high cost of the exam may be a prohibitive factor in many cases (GOOKIN et al., 2004).

A large variety of molecular protocols were developed for the detection of T. foetus in cattle and felines (HO et al., 1994; FELLEISEN et al., 1998; GOOKIN et al., 2002; BONDURANT et al., 2003; GRAHN et al., 2005). Many tests rely on amplification of the 5.8S rRNA gene sequences using ITS1 and ITS2, which are more conserved regions among isolates (FELLEISEN, 1997). The most-used technique is the nested PCR, where two primer pairs are used, TFR 3 and TFR 4 and TFITS-F and TFITS-R (GOOKIN et al., 2002). Several studies have shown that the rRNA gene sequence is highly conserved among T. foetus isolates, and is reliably different from those of other trichomonads
(GOOKIN et al., 2002). Therefore, primers TFR3 and TFR 4 were specially designed to amplify the $347 \mathrm{bp}$ fragment of $T$. foetus DNA (GOOKIN et al., 2002). The second primer pair (TFITS-F and TFITS-R) amplifies a $208 \mathrm{bp}$ fragment of the rRNA gene, which binds to the sequence amplified by the primer pair as previously described (GOOKIN et al., 2003). The combined use of these pairs of primers (TFR3 and TFR 4 with TFITS-F and TFITS-R) results in the detection of 50 parasites per gram of feces $90 \%$ of the time, and 500 parasites per gram of feces $100 \%$ of the time (GOOKIN et al., 2002). One such study showed that nested PCR (single tube) did not amplify the genomic DNA of feline isolates of Giardia sp. or P. hominis.

The reduced sensitivity of PCR for the detection of T. foetus in feces is due to the presence of inhibitors in feces, which are not found in other substances, such as blood. The composition of feces is biologically complex, dependent on the intestinal flora, diet, and concomitant diseases (KATHER et al., 2007). Fecal components, such as polysaccharide complexes, bile salts, hemoglobin degradation products, phenolic compounds, and heavy metals are generally co-extracted with the pathogen DNA and may interfere with the PCR (GOOKIN et al., 2002; STAUFFER et al., 2008). Presence of bacteria also interfere with $T$. foetus identification by PCR, as well as in the fecal culture (CLOTHIER et al., 2015).

A DNA sample can be tested for the presence of inhibitors through a separate reaction, where bacterial $16 S$ rRNA genes are amplified. If these genes cannot be amplified, PCR inhibitors are present in the fecal sample (GOOKIN et al., 2006). To minimize the false-negative results caused by the presence of inhibitors, there are techniques that optimize fecal material extraction, using proteinase $\mathrm{K}$ and temperature optimization, and the use of an additional washing step prior to DNA elution (GOOKIN et al., 2002).

\section{Histopathology}

The trophozoites of $T$. foetus can also be detected in the large intestine by histopathology, but their preservation in the biopsy specimens is difficult, because of its fragility. Yaeger and Gookin (2005) observed parasites in formalin-fixed colon tissues. Immunohistochemistry, fluorescence, and chromogenic in situ hybridization are techniques developed to localize and identify the parasite in tissue samples maintained in formalin, but are not commercially available (GOOKIN et al., 2010).

\section{Treatment}

The search for an effective and safe treatment for feline T. foetus infection is ongoing. The parasite demonstrated a poor sensitivity to several antimicrobial drugs, including metronidazole and tinidazole, drugs commonly used to treat intestinal protozoa and human vaginal trichomonosis (GOOKIN et al., 1999; ROMATOWSKI, 2000; GOOKIN et al., 2001; KATHER et al., 2007).

Ronidazole is currently the drug of choice for treatment (GOOKIN et al., 2006). The drug is rapidly absorbed into the proximal small intestine, metabolized, and eliminated by the liver and kidneys (ROSADO et al., 2007; LEVINE et al., 2011). 
The current recommended dose is $30 \mathrm{mg} / \mathrm{kg}$ once daily for a period of 14 days (LEVINE et al., 2011). High doses of ronidazole are associated with signs of neurotoxicity in cats, with changes occurring at least three days after treatment and ceasing within one to four weeks after discontinuation (ROSADO et al., 2007). The neurotoxic effects are dose-dependent and can be attributed to the long half-life of the drug. Cats with neurotoxicity may exhibit loss of appetite, mental changes, lethargy, ataxia, facial tremors, hyperesthesia, weakness in the pelvic limbs, and occasionally convulsions (LEVINE et al. 2011). These cats may require intensive veterinary support until the side effects resolve (ROSADO et al., 2007).

After administration of the drug, the consistency of the feces of the infected cats generally improves rapidly in days and normalizes after the treatment of two weeks (GOOKIN et al., 2006; BURGENER et al., 2009; HOLLIDAY et al., 2009; BELL et al., 2010). In some cases of infected cats, diarrhea may not resolve for weeks after treatment due to severe colitis (TOLBERT \& GOOKIN, 2009). Symptoms may return after treatment, since complete elimination of the parasite does not always occur (BURGENER et al., 2009; GOOKIN et al., 2010). Infection usually resolves after repeated treatment (GOOKIN et al., 2006). Studies have shown that treatment with other drugs such as fenbendazole, paromomycin, tinidazole, metronidazole, and furazolidone improved the consistency of feces during the treatment period, but the parasite was not eradicated, so diarrhea returned when the medications ceased (KATHER et al., 2007).

\section{Prognosis}

The prognosis for feline T. foetus infection is good. After infection, many cats maintain themselves with normal physical condition. In $88 \%$ of cats with diarrhea, fecal consistency returns to normal spontaneously after 2 years of infection (FOSTER et al., 2004).

The mean duration of diarrhea is 135 days (XENOULIS et al., 2010). However, the spontaneous elimination of $T$. foetus is rare. Recurrent diarrhea associated with stress or changes in the intestinal flora are common (FOSTER et al., 2004). In addition, studies reveal that chronic infection may predispose cats to develop inflammatory bowel disease (GOOKIN et al., 2001).

\section{Prevention}

Kittens or young animals raised in environments with agglomerations are more susceptible to infection due to stress or immune immaturity. Thus, minimizing stress and avoiding overpopulation would be important to reduce the chance of exposure to the agent and development of trichomonosis. As previously mentioned, the parasite is stable and viable in the environment for several days, which emphasizes the need for adequate disinfection of beds, transport boxes, litterboxes, and fomites (HALE et al., 2009).

\section{Conclusion}

Feline trichomonosis is a recent concern in veterinary medicine, caused by the parasite $T$. foetus. Infected cats can be asymptomatic or can present with chronic diarrhea. The diagnosis may be challenging as it demands more specific tests, such as fecal culture and PCR. Unfortunately, testing is still not routine in most veterinary clinics. Knowledge of this new emerging disease is important for the adequate parasite detection and treatment.

\section{References}

Adl SM, Simpson AG, Farmer MA, Andersen RA, Anderson OR, Barta $\mathrm{JR}$, et al. The new higher level classification of eukaryotes with emphasis on the taxonomy of protists. J Eukaryot Microbiol 2005; 52(5): 399-451. http://dx.doi.org/10.1111/j.1550-7408.2005.00053.x. PMid:16248873.

Arranz-Solís D, Pedraza-Díaz S, Miró G, Rojo-Montejo S, Hernández L, Ortega-Mora LM, et al. Tritrichomonas foetus infection in cats with diarrhea from densely housed origins. Vet Parasitol 2016; 221: 118-122. http://dx.doi.org/10.1016/j.vetpar.2016.03.019. PMid:27084482.

Barr SC. Enteric protozoal infections. In: Greene CE. Infectious diseases of the dog and cat. 2nd ed. Philadelphia: WB Saunders; 1998. p. 482-91.

Bell ET, Gowan RA, Lingard AE, McCoy RJ, Slapeta J, Malik R. Naturally occurring Tritrichomonas foetus infections in Australian cats: 38 cases. J Feline Med Surg 2010; 12(12): 889-898. http://dx.doi.org/10.1016/j. jfms.2010.06.003. PMid:20817588.

Bissett SA, Gowan RA, O’Brien CR, Stone MR, Gookin JL. Feline diarrhoea associated with Tritrichomonas foetus and Giardia co-infection in an Australian cattery. Aust Vet J2008; 86(11): 440-443. http://dx.doi. org/10.1111/j.1751-0813.2008.00356.x. PMid:18959533.

Bissett SA, Stone ML, Malik R, Norris JM, O’Brien C, Mansfield CS, et al. Observed occurrence of Tritrichomonas foetus and other enteric parasites in Australian cattery and shelter cats. J Feline Med Surg 2009; 11(10): 803-807. http://dx.doi.org/10.1016/j.jfms.2009.02.001. PMid:19285895.

BonDurant RH, Campero CM, Anderson ML, Van Hoosear KA. Detection of Tritrichomonas foetus by polymerase chain reaction in cultured isolates, cervicovaginal mucus, and formalin-fixed tissues from infected heifers and fetuses. J Vet Diagn Invest 2003; 15(6): 579-584. http://dx.doi.org/10.1177/104063870301500613. PMid:14667024.

Brugerolle G, Lee J. Phylum Parabasalia. In: Lee J, Leedale G, Bradbury P (eds.). The Illustrated Guide to the Protozoa. 2nd ed. Society of Protozoologists, Lawrence; 2000. p. 1196-1210.

Brumpt E. Recherches morphologiques et expérimentales sur le Trichomonas felis Da Cunha et Muniz, 1922, parasite du chat et du chien. Ann Parasitol Hum Comp 1925; 3(3): 239-251. http://dx.doi.org/10.1051/ parasite/1925033239.

Burgener I, Frey CF, Kook P, Gottstein B. Tritrichomonas foetus: a new intestinal parasite in Swiss cats. Schweiz Arch Tierheilkd 2009; 151(8): 383 389. http://dx.doi.org/10.1024/0036-7281.151.8.383. PMid:19653162.

Burgess DE, McDonald CM. Analysis of adhesion and cytotoxicity of Tritrichomonas foetus to mammalian cells by use of monoclonal antibodies. Infect Immun 1992; 60(10): 4253-4259. PMid:1398936.

Ceplecha V, Svoboda M, Cepicka I, Husnik R, Horackova K, Svobodova V. InPouch ${ }^{\mathrm{TM}} \mathrm{TF}-\mathrm{Feline}$ medium is not specific for Tritrichomonas foetus. 
Vet Parasitol 2013; 196(3-4): 503-505. http://dx.doi.org/10.1016/j. vetpar.2013.04.015. PMid:23643452.

Ceplecha V, Svobodova V, Lendon C, Husnik R, Horackova K, Svoboda M. A survey of feline trichomonosis suggests a low incidence of Tritrichomonas blagburni among cats in the Czech Republic. Vet Med 2017; 62(5): 269273. http://dx.doi.org/10.17221/106/2016-VETMED.

Clothier KA, Villanueva M, Torain A, Hult C, Wallace R. Effects of bacterial contamination of media on the diagnosis of Tritrichomonas foetus by culture and real-time PCR. Vet Parasitol 2015; 208(3-4): 143149. http://dx.doi.org/10.1016/j.vetpar.2015.01.006. PMid:25639514.

Dąbrowska J, Karamon J, Kochanowski M, Jędryczko R, Cencek T. Tritrichomonas foetus infection in cat - first detection in Poland. Acta Parasitol 2015; 60(4): 605-608. http://dx.doi.org/10.1515/ap-20150084. PMid:26408578.

DaCunha AM, Muniz J. Sobre um flagellado parasito do gato. Trab Inst Oswaldo Cruz 1922; 36: 285-286.

Dahlgren SS, Gjerde B, Pettersen HY. First record of natural Tritrichomonas foetus infection of the feline uterus. J Small Anim Pract 2007; 48(11): 654-657. http://dx.doi.org/10.1111/j.1748-5827.2007.00405.x. PMid:17725583

Dimski DS. Helminth and noncoccidial protozoan parasites of the gastrointestinal tract. In: Sherding RG, editors. The Cat: Diseases and Clinical Management, 2nd ed. New York: Churchill Livingstone; 1989. p. $459-477$

Doi J, Hirota J, Morita A, Fukushima K, Kamijyo H, Ohta H, et al. Intestinal Tritrichomonas suis (=T. foetus) infection in Japanese cats. $J$ Vet Med Sci 2012; 74(4): 413-417. http://dx.doi.org/10.1292/jvms.110171. PMid:22104396.

Duarte RP, Rocha PRDA, Nakamura AA, Cipriano RS, Viol MA, Melo GD, et al. Detection of natural occurrence of Tritrichomonas foetus in cats in Araçatuba, São Paulo, Brazil. Pesq Vet Bras 2018; 38(2): 309-314. http://dx.doi.org/10.1590/1678-5150-pvb-5115.

Felleisen RS, Lambelet N, Bachmann P, Nicolet J, Muller N, Gottstein B. Detection of Tritrichomonas foetus by PCR and DNA enzyme immunoassay based on rRNA gene unit sequences. J Clin Microbiol 1998; 36(2): 513519. PMid:9466768.

Felleisen RS. Comparative sequence analysis of $5.8 \mathrm{~S}$ rRNA genes and internal transcribed spacer (ITS) regions of trichomonadid protozoa. Parasitology 1997; 115(Pt 2): 111-119. http://dx.doi.org/10.1017/ S0031182097001212. PMid:10190167.

Felleisen RS. Host-parasite interaction in bovine infection with Tritrichomonas foetus. Microbes Infect 1999; 1(10): 807-816. http://dx.doi.org/10.1016/ S1286-4579(99)80083-5. PMid:10816086.

Foster DM, Gookin JL, Poore MF, Stebbins ME, Levy MG. Outcome of cats with diarrhea and Tritrichomonas foetus infection. J Am Vet Med Assoc 2004; 225(6): 888-892. http://dx.doi.org/10.2460/javma.2004.225.888. PMid:15485048.

Frey CF, Schild M, Hemphill A, Stünzi P, Müller N, Gottstein B, et al. Intestinal Tritrichomonas foetus infection in cats in Switzerland detected by in vitro cultivation and PCR. Parasitol Res 2009; 104(4): 783-788. http://dx.doi.org/10.1007/s00436-008-1255-2. PMid:18998166.

Gookin JL, Birkenheuer AJ, Breitschwerdt EB, Levy MG. Single-tube nested PCR for diagnosis of Tritrichomonas foetus in feline feces. J Vet Clin Microbiol 2002; 40(11): 4126-4130. http://dx.doi.org/10.1128/ JCM.40.11.4126-4130.2002. PMid:12409385.
Gookin JL, Birkenheuer AJ, St John V, Spector M, Levy MG. Molecular characterization of trichomonads from feces of dogs with diarrhea. $J$ Parasitol2005; 91(4): 939-943. http://dx.doi.org/10.1645/GE-474R.1. PMid: 17089769

Gookin JL, Breitschwerdt EB, Levy MG, Gager RB, Benrud JG. Diarrhea associated with trichomonosis in cats. J Am Vet Med Assoc 1999; 215(10): 1450-1454. PMid:10579040.

Gookin JL, Copple CN, Papich MG, Poore MF, Stauffer SH, Birkenheuer AJ, et al. Efficacy of ronidazole for treatment of feline Tritrichomonas foetus infection. J Vet Intern Med 2006; 20(3): 536-543. http://dx.doi. org/10.1111/j.1939-1676.2006.tb02893.x. PMid:16734086.

Gookin JL, Foster DM, Poore MF, Stebbins ME, Levy MG. Use of a commercially available culture system for diagnosis of Tritrichomonas foetus infection in cats. J Am Vet Med Assoc 2003; 222(10): 1376-1379. http://dx.doi.org/10.2460/javma.2003.222.1376. PMid:12762381.

Gookin JL, Hanrahan K, Levy MG. The conundrum of feline trichomonosis. J Feline Med Surg 2017; 19(3): 261-274. http://dx.doi. org/10.1177/1098612X17693499. PMid:28245739.

Gookin JL, Levy MG, Law JM, Papich MG, Poore MF, Breitschwerdt EB. Experimental infection of cats with Tritrichomonas foetus. Am J Vet Res 2001; 62(11): 1690-1697. http://dx.doi.org/10.2460/ajvr.2001.62.1690. PMid:11703009.

Gookin JL, Stauffer SH, Coccaro MR, Poore MF, Levy MG, Papich MG. Efficacy of tinidazole for treatment of cats experimentally infected with Tritrichomonas foetus. Am J Vet Res 2007; 68(10): 1085-1088. http:// dx.doi.org/10.2460/ajvr.68.10.1085. PMid:17916015.

Gookin JL, Stebbins ME, Hunt E, Burlone K, Fulton M, Hochel R, et al. Prevalence of and risk factors for feline Tritrichomonas foetus and Giardia infection. J Clin Microbiol 2004; 42(6): 2707-2710. http://dx.doi. org/10.1128/JCM.42.6.2707-2710.2004. PMid:15184456.

Gookin JL, Stone MR, Yaeger MJ, Meyerholz DK, Moisan P. Fluorescence in situ hybridization for identification of Tritrichomonas foetus in formalin-fixed and paraffin-embedded histological specimens of intestinal trichomoniasis. Vet Parasitol 2010; 172(1-2): 139-143. http://dx.doi. org/10.1016/j.vetpar.2010.04.014. PMid:20447769.

Grahn RA, BonDurant RH, van Hoosear KA, Walker RL, Lyons LA. An improved molecular assay for Tritrichomonas foetus. Vet Parasitol 2005; 127(1): 33-41. http://dx.doi.org/10.1016/j.vetpar.2004.08.018. PMid: 15619373.

Gray SG, Hunter AS, Stone MR, Gookin JL. Assessment of reproductive tract disease in cats at risk for Tritrichomonas foetus infection. Am J Vet Res 2010; 71(1): 76-81. http://dx.doi.org/10.2460/ajvr.71.1.76. PMid:20043785.

Gunn-Moore DA, McCann TM, Reed N, Simpson KE, Tennant B. Prevalence of Tritrichomonas foetus infection in cats with diarrhoea in the UK. J Feline Med Surg 2007; 9(3): 214-218. http://dx.doi.org/10.1016/j. jfms.2007.01.003. PMid:17446107.

Gunn-Moore DA, Tennant B. Tritrichomonas foetus diarrhoea in cats. Vet Rec 2007; 160(24): 850-851. http://dx.doi.org/10.1136/vr.160.24.850-b. PMid:17575251

Hale S, Norris JM, Slapeta J. Prolonged resilience of Tritrichomonas foetus in cat faeces at ambient temperature. Vet Parasitol 2009; 166(1-2): 6065. http://dx.doi.org/10.1016/j.vetpar.2009.07.032. PMid:19683398.

Ho MS, Conrad PA, Conrad PJ, LeFebvre RB, Perez E, BonDurant RH. BonDurant RH. Detection of bovine trichomoniasis with a specific 
DNA probe and PCR amplification system. J Clin Microbiol 1994; 32(1): 98-104. PMid:8126211.

Holliday M, Deni D, Gunn-Moore DA. Tritrichomonas foetus infection in cats with diarrhoea in a rescue colony in Italy. J Feline Med Surg 2009; 11(2): 131-134. http://dx.doi.org/10.1016/j.jfms.2008.06.004. PMid:18774326.

Hora AS, Miyashiro SI, Cassiano FC, Brandão PE, Reche-Junior A, Pena HFJ. Report of the first clinical case of intestinal trichomoniasis caused by Tritrichomonas foetus in a cat with chronic diarrhoea in Brazil. BMC Vet Res 2017; 13(1): 109. http://dx.doi.org/10.1186/s12917-017-10263. PMid:28412947.

Hosein A, Kruth AS, Pearl DL, Richardson D, Maggs JC, Peach HA, et al. Isolation of Tritrichomonas foetus from cats sampled at a cat clinic, cat shows and a humane society in southern Ontario. J Feline Med Surg 2013; 15(8): 706-711. http://dx.doi.org/10.1177/1098612X13475617. PMid:23362340.

Jordan HE. Trichomonas spp. in feline: a case report. Vet Med 1956; 51: $23-24$

Kather EJ, Marks SL, Kass PH. Determination of the in vitro susceptibility of feline Tritrichomonas foetus to 5 Antimicrobial agents. J Vet Intern Med 2007; 21(5): 966-970. http://dx.doi.org/10.1111/j.1939-1676.2007. tb03050.x. PMid:17939550.

Kessel JF. Trichomoniasis in kittens. Trans R Soc Trop Med Hyg 1928; 22(1): 61-80. http://dx.doi.org/10.1016/S0035-9203(28)90155-8.

Kingsbury DD, Marks SL, Cave NJ, Grahn RA. Identification of Tritrichomonas foetus and Giardia spp. infection in pedigree show cats in New Zealand. N Z Vet J 2010; 58(1): 6-10. http://dx.doi.org/10.10 80/00480169.2010.65054. PMid:20200569.

Klein B, Langbein-Detsch I, Muller E, Heusinger A. Prävalenz von Tritrichomonas foetus in Kotproben von Katzen mit Durchfall aus Deutschland. Kleintiermedizin 2010; 7/8: 243-247.

Köster LS, Chow C, Yao C. Trichomonosis in cats with diarrhoea in Hong Kong, China, between 2009 and 2014. JFMS Open Rep 2015; 1(2): 2055116915623561 . PMid:28491403.

Kuehner KA, Marks SL, Kass PH, Sauter-Louis C, Grahn RA, Barutzki D, et al. Tritrichomonas foetus infection in purebred cats in Germany: prevalence of clinical signs and the role of co-infection with other enteroparasites. J Feline Med Surg 2011; 13(4): 251-258. http://dx.doi. org/10.1016/j.jfms.2010.12.002. PMid:21288749.

LeVine DN, Papich MG, Gookin JL, Davidson GS, Davis JL, Hayes RB. Ronidazole pharmacokinetics after intravenous and oral immediate-release capsule administration in healthy cats. J Feline Med Surg 2011; 13(4): 244-250. http://dx.doi.org/10.1016/j.jfms.2010.12.001. PMid:21239199.

LeVine DN. Veterinary Protozoology, 1st ed. Ames: ISU Press; 1985.

Levy MG, Gookin JL, Poore M, Birkenheuer AJ, Dykstra MJ, Litaker RW. Tritrichomonas foetus and not Pentatrichomonas hominis is the etiologic agent of feline trichomonal diarrhea. J Parasitol 2003; 89(1): 99-104. http://dx.doi.org/10.1645/0022-3395(2003)089[0099:TFANPH]2.0. CO;2. PMid:12659310.

Lim S, Park SI, Ahn KS, Oh DS, Ryu JS, Shin SS. First report of feline intestinal trichomoniasis caused by Tritrichomonas foetus in Korea. Korean J Parasitol 2010; 48(3): 247-251. http://dx.doi.org/10.3347/ kjp.2010.48.3.247. PMid:20877505.
Lun ZR, Chen XG, Zhu XQ, Li XR, Xie MQ. Are Tritrichomonas foetus and Tritrichomonas suis synonyms? Trends Parasitol 2005; 21(3): 122-125. http://dx.doi.org/10.1016/j.pt.2004.12.001. PMid:15734659.

Mancianti F, Nardoni S, Mugnaini L, Zambernardi L, Guerrini A, Gazzola $\mathrm{V}$, et al. A retrospective molecular study of select intestinal protozoa in healthy pet cats from Italy. J Feline Med Surg 2015; 17(2): 163-167. http:// dx.doi.org/10.1177/1098612X14533549. PMid:24793744.

Mardell EJ, Sparkes AH. Chronic diarrhoea associated with Tritrichomonas foetus infection in a British cat. Vet Rec 2006; 158(22): 765-766. http:// dx.doi.org/10.1136/vr.158.22.765. PMid:16751313.

Miró G, Hernández L, Montoya A, Arranz-Solís D, Dado D, Rojo-Montejo $S$, et al. First description of naturally acquired Tritrichomonas foetus infection in a Persian cattery in Spain. Parasitol Res 2011; 109(4): 11511154. http://dx.doi.org/10.1007/s00436-011-2359-7. PMid:21509446.

Morin-Adeline V, Lomas R, O’Meally D, Stack C, Conesa A, Šlapeta J. Comparative transcriptomics reveals striking similarities between the bovine and feline isolates of Tritrichomonas foetus: consequences for in silico drug-target identification. BMC Genomics 2014; 15(1): 955. http:// dx.doi.org/10.1186/1471-2164-15-955. PMid:25374366.

Mostegl MM, Wetscher A, Richter B, Nedorost N, Dinhopl N, Weissenbock H. Detection of Tritrichomonas foetus and Pentatrichomonas hominis in intestinal tissue specimens of cats by chromogenic in situ hybridization. Vet Parasitol 2012; 183(3-4): 209-214. http://dx.doi.org/10.1016/j. vetpar.2011.07.050. PMid:21856079.

Mugnaini L, Papini R, Gorini G, Passantino A, Merildi V, Mancianti F. Pattern and predictive factors of endoparasitism in cats in Central Italy. Rev Med Vet 2012; 163(2): 89-94.

Paris JK, Wills S, Balzer HJ, Shaw D, Gunn-Moore D. Enteropathogen co-infection in UK cats with diarrhoea. BMC Vet Res 2014; 10(1): 13. http://dx.doi.org/10.1186/1746-6148-10-13. PMid:24410914.

Pereira-Neves A, Benchimol M. Tritrichomonas foetus: budding from multinucleated pseudocysts. Protist 2009; 160(4): 536-551. http://dx.doi. org/10.1016/j.protis.2009.05.001. PMid:19616999.

Pereira-Neves A, Ribeiro KC, Benchimol M. Pseudocysts in trichomonads - new insights. Protist 2003; 154(3-4): 313-329. http://dx.doi. org/10.1078/143446103322454095. PMid:14658492.

Pham D. Chronic intermittent diarrhea in a 14-month-old Abyssinian cat. Can Vet J 2009; 50(1): 85-87. PMid:19337620.

Polak KC, Levy JK, Crawford PC, Leutenegger CM, Moriello KA. Infectious diseases in large-scale cat hoarding investigations. Vet J 2014; 201(2): 189-195. http://dx.doi.org/10.1016/j.tvjl.2014.05.020. PMid:24934262.

Profizi C, Cian A, Meloni D, Hugonnard M, Lambert V, Groud K, et al. Prevalence of Tritrichomonas foetus infections in French catteries. Vet Parasitol 2013; 196(1-2): 50-55. http://dx.doi.org/10.1016/j.vetpar.2013.01.021. PMid:23433647.

Queen EV, Marks SL, Farver TB. Prevalence of selected bacterial and parasitic agents in feces from diarrheic and healthy control cats from Northern California.J Vet Intern Med 2012; 26(1): 54-60. http://dx.doi. org/10.1111/j.1939-1676.2011.00843.x. PMid:22182203.

Raab O, Greenwood S, Vanderstichel R, Gelens H. A cross-sectional study of Tritrichomonas foetus infection in feral and shelter cats in Prince Edward Island, Canada. Can Vet J2016; 57(3): 265-270. PMid:26933262.

Romatowski J. An uncommon protozoan parasite (Pentatrichomonas hominis) associated with colitis in three cats. Feline Pract 1996; 24(5): 10-14. 
Romatowski J. Pentatrichomonas hominis infection in four kittens. J Am Vet Med Assoc 2000; 216(8): 1270-1272. http://dx.doi.org/10.2460/ javma.2000.216.1270. PMid:10767968.

Rosa IA, Souza W, Benchimol M. Changes in the structural organization of the cytoskeleton of Tritrichomonas foetus during trophozoite-pseudocyst transformation. Micron 2015; 73: 28-35. http://dx.doi.org/10.1016/j. micron.2015.03.008. PMid:25880467.

Rosado TW, Specht A, Marks SL. Neurotoxicosis in 4 cats receiving ronidazole. J Vet Intern Med 2007; 21(2): 328-331. http://dx.doi. org/10.1111/j.1939-1676.2007.tb02968.x. PMid:17427396.

Santos CS, Jesus VL, McIntosh D, Berto BP, Lopes CWG. Co-infection by Tritrichomonas foetus and Pentatrichomonas hominis in asymptomatic cats. Pesq Vet Bras 2015; 35(12): 980-988. http://dx.doi.org/10.1590/ S0100-736X2015001200007.

Schrey C, Mundhenk L, Gruber A, Henning K, Frey C. Tritrichomonas foetus as a cause of diarrhoea in three cats. Kleintierpraxis 2009; 54(2): 93-96.

Skirrow S, BonDurant R, Farley J, Correa J. Efficacy of ipronidazole against trichomoniasis in beef bulls. J Am Vet Med Assoc 1985; 187(4): 405-407. PMid:4030475.

Slapeta J, Craig S, McDonell D, Emery D. Tritrichomonas foetus from domestic cats and cattle are genetically distinct. Exp Parasitol 2010; 126(2): 209-213. http://dx.doi.org/10.1016/j.exppara.2010.04.024. PMid:20438726.

Stauffer SH, Birkenheuer AJ, Levy MG, Marr H, Gookin JL. Evaluation of four DNA extraction methods for the detection of Tritrichomonas foetus in feline stool specimens by polymerase chain reaction.J Vet Diagn Invest 2008; 20(5): 639-641. http://dx.doi.org/10.1177/104063870802000518. PMid: 18776100

Steiner JM, Xenoulis PG, Read SA, Suchodolski JS, Globokar M, Huisinga E, et al. Identification of Tritrichomonas foetus DNA in feces from cats with diarrhea from Germany and Austria. J Vet Intern Med 2007; 21(3): 649.

Stockdale H, Rodning S, Givens M, Carpenter D, Lenz S, Spencer J, et al. Experimental infection of cattle with a feline isolate of Tritrichomonas foetus. J Parasitol 2007; 93(6): 1429-1434. http://dx.doi.org/10.1645/ GE-1305.1. PMid:18314690.

Stockdale HD, Dillon AR, Newton JC, Bird RC, Bondurant RH, Deinnocentes P, et al. Experimental infection of cats (Felis catus) with Tritrichomonas foetus isolated from cattle. Vet Parasitol 2008; 154(1-2): 156-161. http://dx.doi.org/10.1016/j.vetpar.2008.02.024. PMid:18394809.

Stockdale HD, Givens MD, Dykstra CC, Blagburn BL. Tritrichomonas foetus infections in surveyed pet cats. Vet Parasitol 2009; 160(1-2): 1317. http://dx.doi.org/10.1016/j.vetpar.2008.10.091. PMid:19070434.

Stockdale HD, Spencer JA, Dykstra CC, Blagburn BL, West GS, Hankes T, et al. Feline trichomoniasis: an emerging disease? Compend Contin Educ Vet 2006; 28(6): 463-471.

Sun Z, Stack C, Slapeta J. Sequence differences in the diagnostic region of the cysteine protease 8 gene of Tritrichomonas foetus parasites of cats and cattle. Vet Parasitol 2012; 186(3-4): 445-449. http://dx.doi.org/10.1016/j. vetpar.2011.12.001. PMid:22204891.

Tachezy J, Tachezy R, Hampl V, Sedinová M, Vanacová S, Vrlík M, et al. Cattle pathogen Tritrichomonas foetus (Riedmuller, 1928) and pig commensal Tritrichomonas suis (Gruby \& Delafond, 1843) belong to the same species. J Eukaryot Microbiol 2002; 49(2): 154-163. http:// dx.doi.org/10.1111/j.1550-7408.2002.tb00360.x. PMid:12046599.

Tanabe M. Morphological studies on trichomonas. J Parasitol 1926; 12(3): 120-130. http://dx.doi.org/10.2307/3271220.

Tolbert MK, Gookin JL. Mechanisms of Tritrichomonas foetus Pathogenicity in Cats with Insights from Venereal Trichomonosis. J Vet Intern Med 2016; 30(2): 516-526. http://dx.doi.org/10.1111/jvim.13920. PMid:26946069.

Tolbert MK, Gookin JL. Tritrichomonas foetus: A new agent of feline diarrhea. Compend Contin Educ Vet 2009; 31(8): 374-381, 390, quiz 381. PMid:19866444.

Tysnes K, Gjerde B, Nodtvedt A, Skancke E. A cross-sectional study of Tritrichomonas foetus infection among healthy cats at shows in Norway. Acta Vet Scand 2011; 53(1): 39. http://dx.doi.org/10.1186/1751-014753-39. PMid:21689400.

Van der Saag M, McDonell D, Slapeta J. Cat genotype Tritrichomonas foetus survives passage through the alimentary tract of two common slug species. Vet Parasitol 2010; 177(3-4): 262-266. http://dx.doi.org/10.1016/j. vetpar.2010.11.054. PMid:21185122.

van Doorn DC, De Bruin MJ, Jorritsma RA, Ploeger HW, Schoormans A. Prevalence of Tritrichomonas foetus among Dutch cats. Tijdschr Diergeneeskd 2009; 134(17): 698-700. PMid:19774881.

Vermeulen BD. Tritrichomonas foetus in young cats with chronic diarrhoea: Comparison of different diagnostic methods [PhD Thesis]. Utrecht: Utrecht University; 2009.

Veronesi F, Gazzonis AL, Napoli E, Brianti E, Santoro A, Zanzani SA, et al. Cross-sectional survey on Tritrichomonas foetus infection in Italian cats. Vet Parasitol Reg Stud Rep 2016; 6: 14-19.

Walden HS, Dykstra C, Dillon A, Rodning S, Givens D, Bird R, et al. A new species of Tritrichomonas (Sarcomastigophora: Trichomonida) from the domestic cat (Felis catus). Parasitol Res 2013; 112(6): 22272235. http://dx.doi.org/10.1007/s00436-013-3381-8. PMid:23525691.

Wartona A, Honigberg BM. Structure of trichomonads as revealed by scanning electron microscopy. J Protozool 1979; 26(1): 56-62. http:// dx.doi.org/10.1111/j.1550-7408.1979.tb02732.x. PMid:314517.

Xenoulis PG, Lopinski DJ, Read SA, Suchodolski JS, Steiner JM. Intestinal Tritrichomonas foetus infection in cats: a retrospective study of 104 cases. J Feline Med Surg 2013; 15(12): 1098-1103. http://dx.doi. org/10.1177/1098612X13495024. PMid:23838083.

Xenoulis PG, Saridomichelakis MN, Read SA, Suchodolski JS, Steiner JM. Detection of Tritrichomonas foetus in cats in Greece. J Feline Med Surg 2010; 12(10): 831-833. http://dx.doi.org/10.1016/j.jfms.2010.05.010. PMid:20674428.

Yaeger MJ, Gookin JL. Histologic features associated with Tritrichomonas foetus induced colitis in domestic cats. Vet Pathol 2005; 42(6): 797-804. http://dx.doi.org/10.1354/vp.42-6-797. PMid:16301576.

Yao C, Koster L, Halper B, Dundas J, Nair R. Failure to detect Tritrichomonas foetus in a cross-sectional survey in the populations of feral cats and owned outpatient cats on St Kitts, West Indies. JFMS Open Rep 2018; 4(1); 1-6. PMid:30202541.

Yao C, Koster LS. Tritrichomonas foetus infection, a cause of chronic diarrhea in the domestic cat. Vet Res 2015; 46(1): 35. http://dx.doi. org/10.1186/s13567-015-0169-0. PMid:25880025. 